\title{
PENGELOLAAN SAMPAH KERING LAYAK JUAL DENGAN SISTEM BANK SAMPAH DI KAMPUS UNIVERSITAS ANDALAS PADANG
}

\author{
Yenni Ruslinda \\ Jurusan Teknik Lingkungan, Fakultas Teknik Universitas Andalas \\ Email: yenni@ft.unand.ac.id
}

\begin{abstract}
ABSTRAK
Pengelolaan sampah eksisting yang dilakukan pihak Unand masih menerapkan pola kumpul-angkutPengelolaan sampah kering layak jual dengan sistem bank sampah di kampus Universitas Andalas sudah dioperasikan mulai awal tahun 2014 sejalan dengan pendirian Pusat Pengolahan Sampah Terpadu (PPST Unand). Sampah kering layak jual yang ditabung oleh nasabah ke Bank Sampah Enviro Andalas berupa sampah plastik, sampah kertas dan karton, serta sampah kaleng dan aluminium dengan jumlah berkisar 100-800 kg/bulan. Hasil evaluasi terhadap persyaratan kontruksi dan sistem manajemen serta pelaksanaan bank sampah berdasarkan Peraturan Menteri Lingkungan Hidup Republik Indonesia no 13 tahun 2012 telah memenuhi kriteria yang berlaku. Dalam operasional bank sampah terjadi peningkatan jumlah nasabah, jumlah sampah yang ditabung dan jumlah penjualan sampah ke bandar daur ulang tiap bulannya. Hal ini terkait dengan semakin seringnya sosialisasi dilakukan untuk meningkatkan keaktifan masyarakat kampus dalam pemilahan sampah, dukungan prasarana dan sarana serta komitmen pimpinan universitas untuk mendukung pengelolaan sampah di sumber dengan konsep $3 R$.
\end{abstract}

Kata kunci: $\quad$ bank sampah, kampus Unand, PPST Unand, sampah kering layak jual
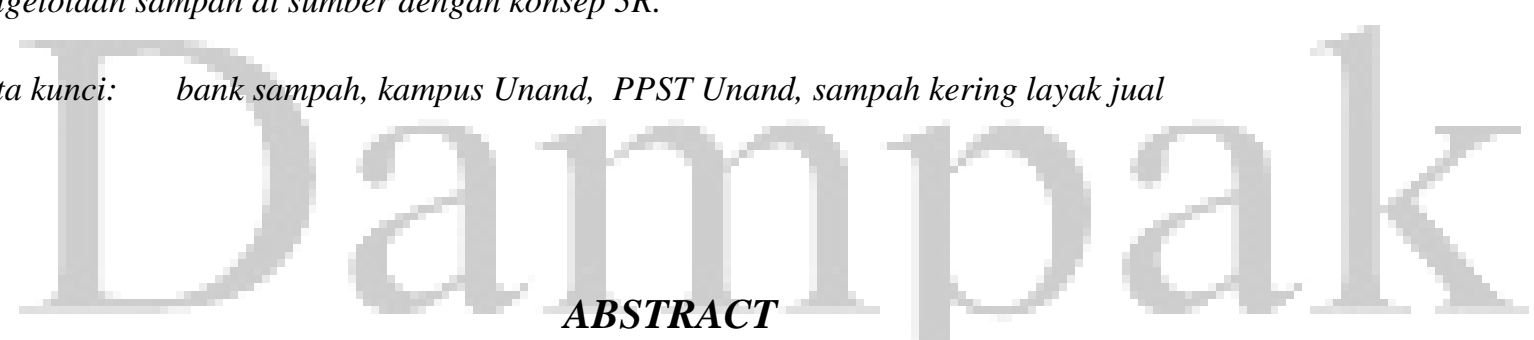

Management of marketable dry waste with waste bank system at Andalas University campus have been operated since early 2014, in line with the establishment of Integrated Waste Processing Center (PPST Unand). Marketable dry waste deposited by the customer to the Enviro Andalas Waste Bank are in the form of plastic, paper and cardboard, cans and aluminum in amount of ranging from 100$800 \mathrm{~kg} / \mathrm{month}$. An evaluation of the construction requirements, management systems and the implementation of waste banks shows that this waste bank system has met the applied criteria based on Peraturan Menteri Lingkungan Hidup Republik Indonesia no. 13/2012. Increasing number of customers, amount of waste deposited, and the amount of waste sold to recycling dealers each month have been occurred during the bank operation. This could be related with more frequent socialization to enhance the campus community in waste segregation, supporting to infrastructure and facilities, and the university leader's commitment to stand up for the management of waste at source with $3 R$ concept.

Keywords: waste bank, marketable dry waste, campus Unand, PPST Unand. 


\section{PENDAHULUAN}

Undang-Undang Nomor 18 tahun 2008 tentang Pengelolaan Sampah beserta Peraturan Pemerintah Nomor 81 Tahun 2012 tentang Pengelolaan Sampah Rumah Tangga dan Sampah Sejenis Sampah Rumah Tangga mengamanatkan perlunya perubahan paradigma yang mendasar dalam pengelolaan sampah yaitu dari paradigma kumpul - angkut - buang menjadi pengolahan yang bertumpu pada pengurangan sampah dan penanganan sampah. Kegiatan pengurangan sampah bermakna agar seluruh lapisan masyarakat, baik pemerintah, dunia usaha maupun masyarakat luas melaksanakan kegiatan pembatasan timbulan sampah, pendauran ulang dan pemanfaatan kembali sampah atau yang lebih dikenal dengan sebutan Reduce, Reuse dan Recycle (3R) melalui upayaupaya cerdas, efisien dan terprogram (Utami, E., 2013)

Namun kegiatan 3R ini masih menghadapi kendala utama, yaitu rendahnya kesadaran masyarakat untuk memilah sampah. Salah satu solusi untuk mengatasi masalah tersebut yaitu melalui pengembangan Bank Sampah yang merupakan kegiatan bersifat social engineering yang mengajarkan masyarakat untuk memilah sampah serta menumbuhkan kesadaran masyarakat dalam pengolahan sampah secara bijak dan pada gilirannya akan mengurangi sampah yang diangkut ke TPA. Pembangunan bank sampah ini harus menjadi momentum awal membina kesadaran kolektif masyarakat untuk memulai memilah, mendaur-ulang, dan memanfaatkan sampah, karena sampah mempunyai nilai jual yang cukup baik, sehingga pengelolaan sampah yang berwawasan lingkungan menjadi budaya baru Indonesia.

Statistik perkembangan pembangunan Bank Sampah di Indonesia pada bulan Februari 2012 adalah 471 buah jumlah Bank Sampah yang sudah berjalan dengan jumlah penabung sebanyak 47.125 orang dan jumlah sampah yang terkelola adalah $755.600 \mathrm{~kg} / \mathrm{bulan}$ dengan nilai perputaran uang sebesar Rp. 1.648.320.000 perbulan. Angka statistik ini meningkat menjadi 886 buah Bank Sampah berjalan sesuai data bulan Mei 2012, dengan jumlah penabung sebanyak 84.623 orang dan jumlah sampah yang terkelola sebesar $2.001 .788 \mathrm{~kg} / \mathrm{bulan}$ serta menghasilkan uang sebesar Rp. 3.182.281.000 perbulan. (KLHRI, 2012)

Dalam rangka mewujudkan pengelolaan sampah 3R mulai dari sumber dan berbasis masyarakat sesuai amanat UU RI no 18 tahun 2008, di kampus Universitas Andalas Limau Manis sudah didirikan Pusat Pengolahan Sampah Terpadu Universitas Andalas (PPST Unand) mulai tahun 2014. Pengolahan yang dilakukan di PPST Unand meliputi pengelolaan sampah kering (anorganik) layak jual dengan penerapan bank sampah, pengelolaan sampah basah (organik) layak kompos dengan pengomposan dan pengelolaan sampah sisa (residu) dengan insinerasi. (Ruslinda, dkk, 2014)

Pendirian PPST ini juga didasarkan pada hasil penelitian Chania tahun 2010 terhadap timbulan, komposisi dan potensi daur ulang sampah kampus Unand Limau Manis. Hasil penelitian menunjukkan satuan timbulan rata-rata sampah kampus Unand Limau Manis adalah 0,784 liter/orang/hari atau 0,12 $\mathrm{kg} /$ orang/hari dengan komposisi sampah terdiri dari sampah sisa makanan $26,60 \%$, sampah kertas 25,25\%, sampah plastik $30,04 \%$, sampah tekstil 0,19\%, sampah karet $0,05 \%$, sampah kayu $1,18 \%$, sampah halaman 9,76\%, sampah kaca 1,13\%, sampah kaleng $1,33 \%$, sampah logam $0,12 \%$ dan sampah lain-lain 4,35\%. Komponen sampah yang berpotensi untuk di daur ulang adalah sampah kertas 59,98\%, sampah plastik 96,37\%, sampah kaca 93\%, sampah kayu 97,3\%, sampah halaman $100 \%$, sampah makanan $85,44 \%$ dan sampah kaleng $85,81 \%$, sehingga diperoleh rata-rata potensi daur ulang sampah kampus Unand mencapai 80\% (Chania, 2010).

Dengan melihat besarnya komposisi sampah kertas dan plastik yang dihasilkan dan potensi daur ulangnya sebesar $50-90 \%$, maka dalam pengelolaannya sampah yang tergolong sampah kering layak jual ini didaur ulang dengan penerapan sistem bank sampah. Untuk mengevaluasi sejauh mana pengelolaan sampah kering layak jual dengan sistem bank sampah di kampus 
Unand dilakukan pembahasannya dalam tulisan ini

\section{BAHASAN UTAMA}

\section{Perhitungan Material Balance Sampah Kampus Unand Limau Manis}

Tabel 1 memperlihatkan perhitungan material balance sampah kampus Unand Limau Manis. Pada tabel tersebut didapatkan jumlah sampah kering lebih besar dibandingkan jumlah sampah basah. Jumlah sampah kering sebesar $12,5 \mathrm{~m}^{3} /$ hari (2 ton/hari) dan sampah basah $7,5 \mathrm{~m}^{3} /$ hari (1 ton/hari). Timbulan sampah terbesar adalah sampah plastik, sampah makanan dan sampah kertas dengan jumlah masingmasingnya hampir $6 \mathrm{~m}^{3} /$ hari $( \pm 800 \mathrm{~kg} /$ hari $)$ (Ruslinda, dkk., 2014).

Sesuai hasil penelitian potensi daur ulang, sampah basah berupa sampah makanan, sampah halaman dan sampah kayu berpotensi didaur ulang berkisar $85-100 \%$ dan sampah kering berupa sampah kertas, sampah plastik, sampah kaca dan kaleng berpotensi didaur ulang 60-97\% . Berdasarkan data potensi daur ulang ini didapatkan 1,4 ton/hari sampah kering dan 1 ton/hari sampah basah dapat didaur ulang setiap harinya. Sampah kering ini didaur ulang dengan penjualan kembali ke pemanfaat daur ulang yaitu lapak/bandar daur ulang.

Dari Tabel 1 terlihat sampah kering terbanyak yang dapat didaur ulang adalah sampah plastik sebesar $879 \mathrm{~kg} / \mathrm{hari}$, berikutnya sampah kertas $460 \mathrm{~kg} / \mathrm{hari}$, sampah kaleng $35 \mathrm{~kg} /$ hari dan sampah kaca $32 \mathrm{~kg} /$ hari. Sampah kertas yang dapat didaur ulang berupa koran dan majalah bekas, kertas HVS, kertas buram, kertas karton dan kardus yang dihasilkan dari aktivitas perkantoran dan perkuliahan serta kardus dari aktivitas kantin/café. Sampah plastik umumnya berupa gelas dan botol plastik, serta sisa pembungkus makanan. Sampah plastik ini berasal dari aktivitas kantin/café dan kegiatan rapat, seminar dan pelatihan yang diselenggarakan di lingkungan kampus. Sampah kaleng berupa sisa minuman kaleng, kaleng cat yang berasal dan aktivitas kantin dan pertukangan serta bengkel. Sampah kaca berupa botol serta pecahan gelas dan piring dari aktivitas kantin/café dan laboratorium

Tabel 1 Perhitungan Material Balance Sampah Kampus Unand Limau Manis

\begin{tabular}{|c|c|c|c|c|c|c|}
\hline \multirow{2}{*}{ Komponen sampah } & \multicolumn{2}{|c|}{ Jumlah Sampah } & \multicolumn{2}{|c|}{ Jumlah Sampah yang Didaur ulang } & \multicolumn{2}{|c|}{ Jumlah Sampah Sisa (residu) } \\
\hline & kg/hari & liter/hari & $\mathrm{kg} / \mathrm{hari}$ & liter/hari & kg/hari & liter/hari \\
\hline \multicolumn{7}{|l|}{ Sampah Basah } \\
\hline Sampah makanan & 808 & 5280 & 690 & 4511 & 118 & 769 \\
\hline Sampah halaman & 297 & 1937 & 297 & 1937 & 0 & 0 \\
\hline Sampah kayu & 36 & 234 & 35 & 228 & 1 & 6 \\
\hline Total sampah basah & 1140 & 7451 & 1022 & 6676 & 119 & 775 \\
\hline \multicolumn{7}{|l|}{ Sampah Kering } \\
\hline Sampah kertas & 767 & 5012 & 460 & 3006 & 307 & 2006 \\
\hline Sampah plastik & 913 & 5962 & 879 & 5746 & 33 & 216 \\
\hline Sampah kaca & 34 & 224 & 32 & 209 & 2 & 16 \\
\hline Sampah kaleng & 40 & 264 & 35 & 227 & 6 & 37 \\
\hline Sampah tekstil & 6 & 38 & 0 & 0 & 6 & 38 \\
\hline Sampah karet & 2 & 10 & 0 & 0 & 2 & 10 \\
\hline Sampah logam & 4 & 24 & 0 & 0 & 4 & 24 \\
\hline Sampah lain-lain & 132 & 863 & 0 & 0 & 132 & 863 \\
\hline Total sampah kering & 1898 & 12397 & 1406 & 9187 & 491 & 3210 \\
\hline
\end{tabular}

Sumber: Ruslinda, dkk, 2014

\section{Pendirian Bank Sampah Enviro Andalas}

Pengelolaan sampah kering layak jual seperti sampah kertas, sampah plastik dan sampah kaleng telah dilakukan dengan penerapan bank sampah mulai tahun 2012 . Pendirian bank sampah ini diawali di Jurusan Teknik Lingkungan dan Fakultas Teknik dengan nama Bank Sampah Enviro yang berlokasi di lantai 1 Jurusan Teknik Lingkungan. Operasional kegiatan ini melibatkan mahasiswa yang tergabung dalam tim SWCT (Solid Waste Creative Team) yaitu kelompok mahasiswa yang peduli terhadap masalah persampahan (Edwin, dkk., 2012) 
Selama beroperasi setahun (2012 sd 2013), sudah ada \pm 100 orang nasabah bank sampah, yang umumnya berasal dari mahasiswa dan dosen serta pedagang di lingkungan Fakultas Teknik. Melihat cukup banyak peminat dari kalangan mahasiswa untuk bergabung sebagai nasabah dan cukup semangatnya tim SWCT dalam mengelola bank sampah, disepakati untuk mengembangkan kegiatan bank sampah ini untuk tingkat universitas.

Mulai tahun 2014, dengan adanya hibah dari Dikti dalam kegiatan pengabdian masyarakat untuk skim IbIKK, kegiatan bank sampah ini dikembangkan untuk tingkat universitas. Hal ini sejalan dengan konsep pengelolaan sampah terpadu yang diterapkan universitas dengan mendirikan PPST Unand. Kegiatan di PPST Unand selain pengelolaan sampah kering layak jual dengan sistem bank sampah, juga meliputi pengomposan sampah basah layak kompos dan pengelolaan sampah sisa (residu) dengan insinerasi. Kegiatan ini dilakukan secara bertahap, sehingga nantinya diharapkan semua sampah yang dihasilkan kampus Unand dapat dikelola sendiri dengan konsep 'zero waste'. Hal ini dilakukan mengingat jauhnya lokasi pembuangan sampah kota Air Dingin dari kampus Unand, sehingga membutuhkan biaya yang cukup besar untuk operasional pengangkutannya (Ruslinda, 2014).

Sesuai pengembangan menjadi lingkup universitas, awal tahun 2014 Bank Sampah Enviro berganti nama menjadi Bank Sampah Enviro Andalas. Lokasi bank sampah ini pun pindah ke lokasi PPST Unand di jalan lingkar selatan kampus. Selain itu juga didirikan posko atau gerai bank sampah yang berlokasi di pusat keramaian kampus, yaitu di depan gedung kuliah $\mathrm{F}$ (dekat parkir lapangan bola). Hal ini dilakukan sekalian untuk sosialisasi keberadaan Bank Sampah Enviro Andalas kepada masyarakat kampus. Gambar 1 memperlihatkan lokasi Bank Sampah Enviro Andalas.

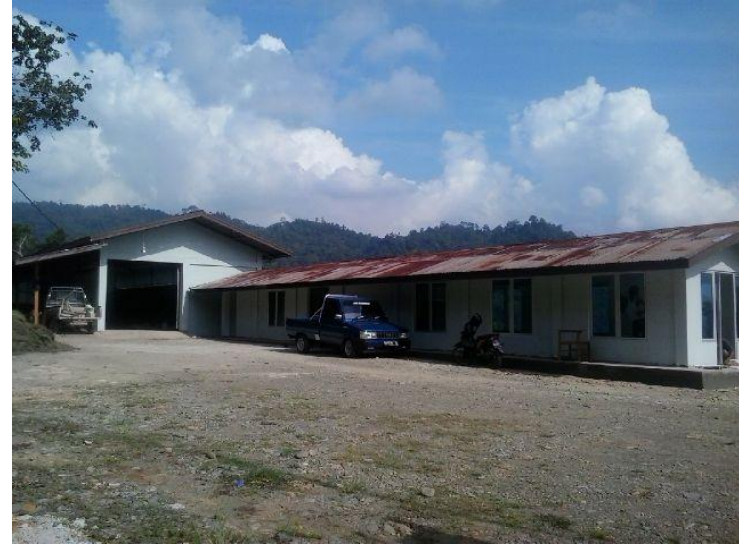

a. Bank Sampah di PPST Unand

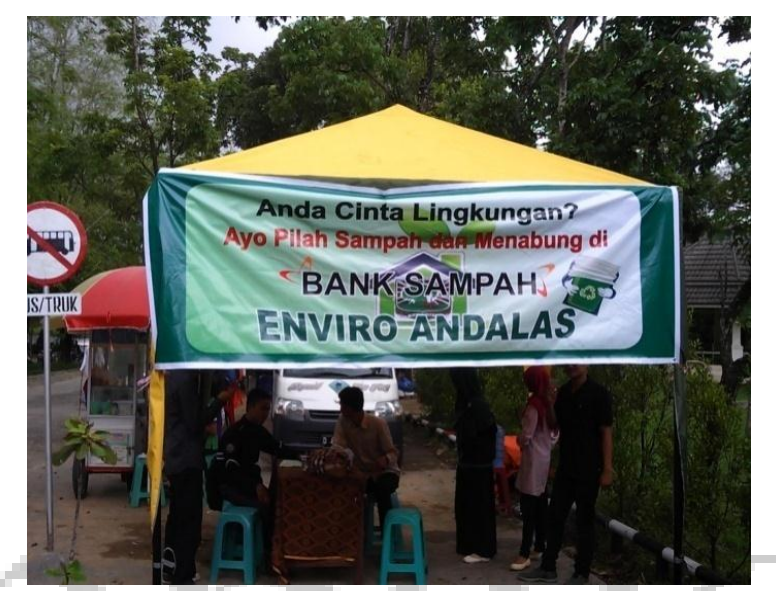

b. Posko/Gerai Bank Sampah

Gambar 1 Lokasi Bank Sampah Enviro Andalas

\section{Operasional Bank Sampah Enviro Andalas}

Bank Sampah Enviro Andalas beroperasi setiap hari kerja yaitu hari Senin sd Jumat dari jam 9.00 sd 15.00. Operasional Bank Sampah Enviro Andalas terdiri dari pendaftaran menjadi nasabah bank sampah, penabungan sampah oleh nasabah, penimbangan sampah yang ditabung oleh petugas bank sampah, pencatatan dan konversi sampah yang ditabung ke rupiah, penjualan sampah oleh petugas bank sampah ke bandar daur ulang serta penarikan

dana tabungan oleh nasabah. Lebih jelasnya tahapan operasional bank sampah dapat dilihat pada Gambar 2

Pendaftaran menjadi nasabah bank dilakukan dengan mengisi formulir kesediaan menjadi nasabah bank serta 
kesediaan mengikuti ketentuan yang berlaku di Bank Sampah Enviro Andalas. Nasabah bank berasal dari masyarakat kampus yaitu dosen, karyawan, mahasiswa dan masyarakat umum yang terdiri dari cleaning service, pedagang kantin/café, atau masyarakat yang berdomisili di sekitar lingkungan kampus. Nasabah bank dapat dilakukan perorangan (individu) atau perkelompok (kolektif). Setelah terdaftar menjadi nasabah, nasabah mendapatkan nomor rekening dan buku tabungan.

Nasabah dapat menabungkan sampahnya ke Bank Sampah Enviro Andalas dengan membawa sampah yang akan ditabung (sesuai dengan jenis sampah yang dapat ditabung di bank sampah) ke lokasi maupun posko bank sampah. Selanjutnya petugas bank sampah menimbang sampah dan menkonversinya ke rupiah (konversi sesuai dengan daftar harga yang berlaku saat itu). Petugas mencatat kegiatan ini di buku tabungan nasabah dan merekapnya pada perangkat komputer di bank sampah.

Tabel 2 memperlihatkan jenis sampah yang dapat ditabung dan daftar harganya. Hingga saat ini jenis sampah yang dapat ditabung adalah gelas plastik, botol plastik, karah, koran, majalah, kertas HVS, kertas buram dan kardus. Harga beli sampah ini bervariasi dari Rp 500 sd Rp. 10.000 per $\mathrm{kg}$, tergantung jenis sampah. Harga sampah tertinggi adalah kaleng minuman, sedangkan yang terendah adalah kertas buram. Harga beli sampah ini bervariasi dan dapat berubah setiap saat, tergantung pada kondisi pasar.

Setelah menerima sampah dari nasabah, petugas bank sampah memilah sampah sesuai jenisnya, kemudian menempatkannya sesuai wadahnya. Hal ini dilakukan untuk memudahkan dalam penanganan selanjutnya, baik untuk penjualan ke bandar daur ulang dan pengolahan lanjutan. Gambar 3 memperlihatkan pemilahan dan pewadahan sampah di bank sampah.
Operasional Bank Sampah Enviro Andalas

(setiap hari kerja jam 9.00 sd 15.00)

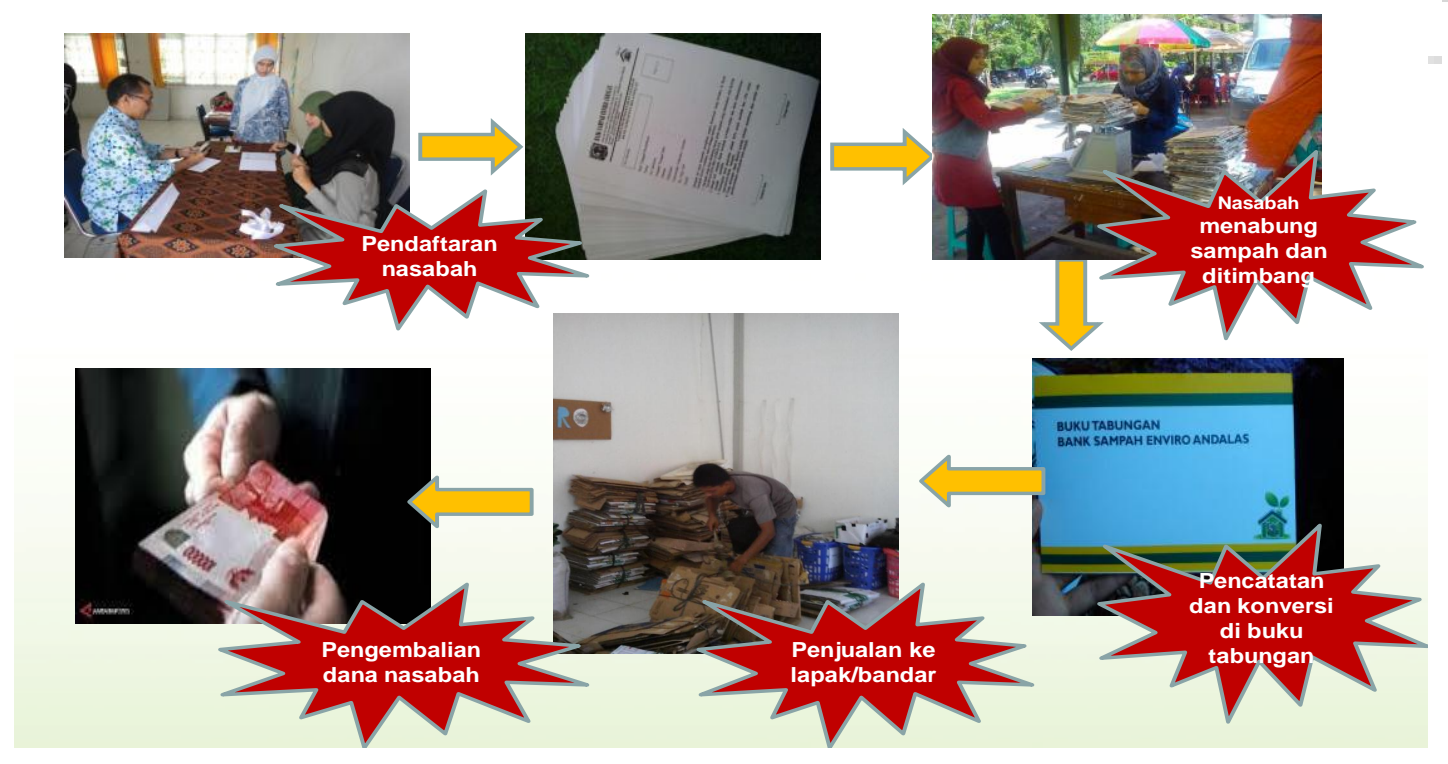

Gambar 2 Tahapan Operasional Bank Sampah Enviro Andalas 


\section{Tabel 2. Jenis Sampah yang Ditabung dan Harga Belinya}

\begin{tabular}{lc}
\hline \multicolumn{1}{c}{ Jenis Sampah yang Ditabung } & Harga Sampah (per kg) \\
\hline Botol Plastik Bening Bersih & $2000-4000$ \\
\hline Botol Plastik Bening tidak Bersih & 2000 \\
\hline Botol plastik tidak Bening bersih & $1000-1300$ \\
\hline $\begin{array}{l}\text { Botol plastik tidak Bening tidak } \\
\text { bersih }\end{array}$ & 1000 \\
\hline Gelas Plastik Bening Bersih & $5000-7000$ \\
\hline Gelas Plastik Bening tidak Bersih & $1500-3500$ \\
\hline Karah & $1000-2500$ \\
\hline Kaleng Susu & $1000-1700$ \\
\hline Kaleng Minuman & $7000-10000$ \\
\hline Kardus & $600-2000$ \\
\hline Kertas HVS & $1200-1500$ \\
\hline Kertas Kotor & 1500 \\
\hline Kertas Koran & $700-1200$ \\
\hline Kulit Kertas & $200-500$ \\
\hline Aluminium & $5000-11000$ \\
\hline
\end{tabular}

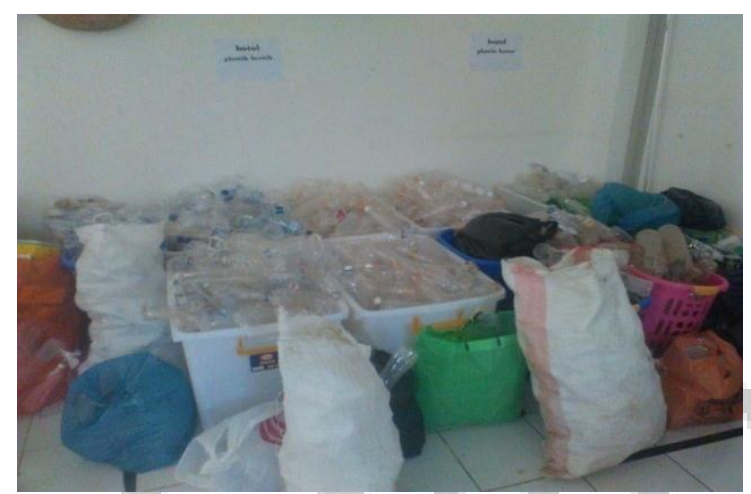

\section{Gambar 3 Pemilahan dan Pewadahan} Sampah

Sebelum di jual ke pemanfaat daur ulang (lapak/bandar), petugas bank sampah melakukan beberapa penanganan terhadap sampah. Untuk sampah kertas dikelompokkan berdasarkan jenisnya, seperti koran, majalah, kardus, kertas HVS, kertas buram dan kulit kertas (karton). Masingmasing jenis kelompok kertas ini diikat dengan tali, untuk memudahkan penjualan. Untuk sampah kaleng, dikelompokkan menjadi kaleng susu/biskuit dan kaleng minuman.

Khusus untuk sampah plastik, pengelompokan didasarkan pada jenisnya seperti gelas plastik bening, gelas plastik tidak bening (berwarna), botol plastik bening, botol plastik tidak bening (berwarna) serta karah (selain gelas dan botol plastik termasuk kemasan shampoo, deterjen, oli dll). Setelah dikelompokkan sesuai jenis dan warnanya, sampah plastik ini dicacah dengan menggunakan mesin pencacah plastik. Hasil cacahan plastik ini kemudian dicuci dalam alat pembersih sampah plastik dan dijemur untuk pengeringan. Setelah kering, sampah plastik tercacah ini dipacking ke dalam karung/kantong plastik. Gambar 4 memperlihatkan pencacahan sampah plastik.

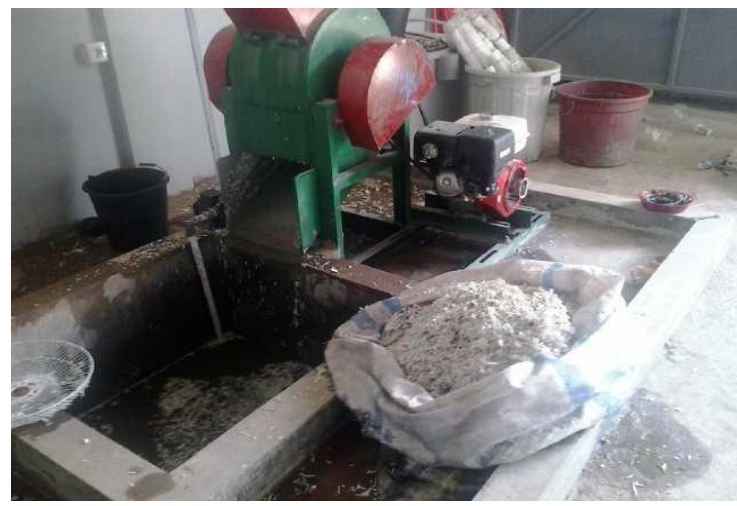

Gambar 4 Pencacahan Sampah Plastik

Tahapan berikutnya dari operasional bank sampah adalah penjualan sampah ke lapak/bandar daur ulang yang menjadi mitra bank sampah. Harga pembelian sampah oleh bandar daur ulang sesuai dengan harga pasaran. Penjualan ke bandar daur ulang ini dilakukan 1-2 kali dalam sebulan, tergantung pada jumlah sampah di gudang bank sampah. Gambar 5 memperlihatkan kegiatan penjualan sampah ke bandar daur ulang.

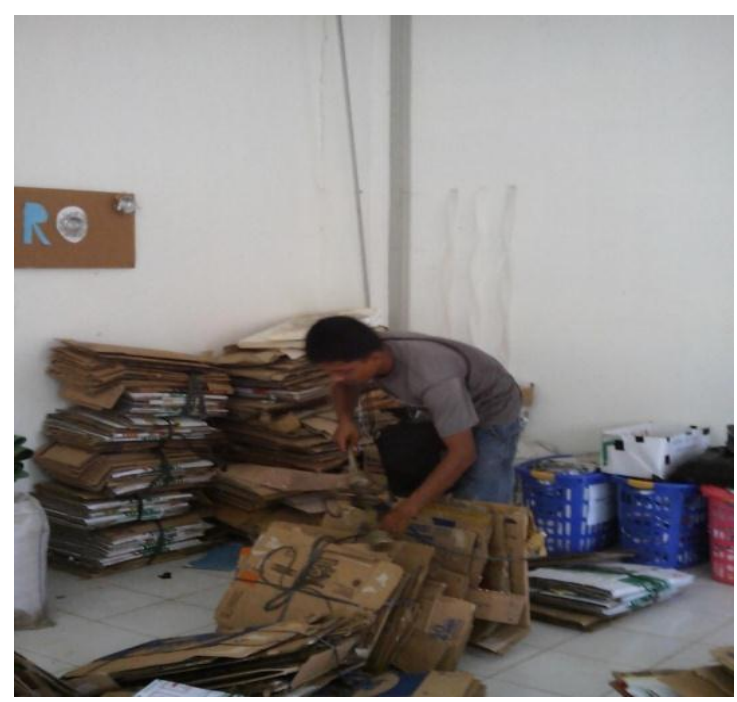

Gambar 5 Penjualan Sampah ke Bandar Daur Ulang

Tahapan terakhir adalah penarikan dana tabungan oleh nasabah. Penarikan dapat dilakukan minimal sebulan setelah sampah 
ditabung. Dalam operasionalnya, Bank Sampah Enviro Andalas sudah melaksanakan sistem bagi hasil 85:15 yaitu $85 \%$ (delapan puluh lima persen) untuk penabung dan 15\% (lima belas persen) untuk pelaksana bank sampah. Jatah 15\% untuk bank sampah digunakan untuk kegiatan operasional bank sampah seperti pembuatan buku rekening, fotokopi, pembelian alat tulis, dan pembelian perlengkapan pelaksanaan operasional bank sampah. Sistem bagi hasil ini sudah disosialisasikan kepada nasabah melalui kegiatan sosialisasi/penyuluhan serta pernyataan yang ada dalam formulir pendaftaran menjadi nasabah bank.

\section{Evaluasi Operasional Bank Sampah Enviro Andalas}

Evaluasi terhadap operasional bank sampah dilakukan setelah pengoperasian selama 9 (sembilan) bulan. Hasil evaluasi meliputi persyaratan dan pelaksanaan bank sampah.

\section{Persyaratan Bank Sampah}

Sesuai Pasal 4 Peraturan Menteri Negara Lingkungan Hidup Republik Indonesia no 13 tahun 2012 tentang Pedoman Pelaksanaan Reduce, Reuse dan Recycle melalui Bank Sampah, persyaratan bank sampah meliputi persyaratan kontruksi dan sistem manajeman bank sampah.

Persyaratan kontruksi untuk bangunan bank sampah meliputi luas bangunan minimal 40 $\mathrm{m}^{2}$ yang dilengkapi dengan lantai dan dinding yang kuat dan bersih, ada ventilasi baik alam (paling sedikit 15\% dari luas lantai) maupun mekanis (AC, fan, exhauster), atap kuat dan tidak bocor, langitlangit minimal 2,7 m dari lantai, ada pintu dan terdapat ruang pelayanan penabung dengan perangkat meubel, timbangan dan pencahayaan yang cukup . Lingkungan bank sampah dilengkapi pagar, halaman, taman, parkir, saluran drainase di sekeliling bangunan (PermenLHRI no. 13 tahun 2012).

Bank Sampah Enviro Andalas yang terletak di lokasi PPST Unand memiliki luas bangunan untuk kantor dan gudang bank sampah sebesar $84 \mathrm{~m}^{2}$, yang juga dilengkapi dengan dapur dan toilet. Bangunan bank sampah ini sudah dilengkapi dengan lantai keramik, dinding bata, tinggi langi-langit dari lantai $3 \mathrm{~m}$ dan ventilasi alam berupa jendela yang cukup untuk pencahayaan. Lingkungan sekitar bank sampah juga sudah dilengkapi dengan halaman, pagar, taman, tempat parkir dan saluran drainase. Dengan demikian luas bangunan dan komponen bangunan Bank Sampah Enviro Andalas telah memenuhi persyaratan kontruksi dalam PermerLHRI no. 13 tahun 2012.

Berdasarkan Lampiran I PermerLHRI no. 13 tahun 2012, standar manajemen bank sampah terdiri dari nama dan alamat bank sampah serta komponen bank sampah yang terdiri dari penabung sampah, pelaksana bank sampah, pengepul/industri daur ulang, pengelolaan sampah di bank sampah. Penabung sampah harus mendapatkan nomor rekening dan buku tabungan dan sudah melakukan pemilahan sampah. Pelaksana bank sampah menggunakan APD (Alat Pelindung Diri) saat melayani penabung sampah, melakukan monev minimal $1 \mathrm{x}$ sebulan dan mendapatkan insentif/gaji setiap bulannya. Pengepul/industri daur ulang mempunyai mou dengan bank sampah serta memiliki izin usaha. Pengelolaan sampah di bank sampah meliputi sampah yang ditabung diambil pengepul paling lama satu bulan sekali, cakupan pelayanan bank sampah minimal 500 KK (2500-3000 orang) serta bertambahnya nasabah 5-10 orang setiap bulannya.

Berdasarkan standar manajemen bank sampah di atas, untuk nama dan alamat, Bank Sampah Enviro Andalas sudah memenuhi kriteria tersebut. Untuk semua komponen bank sampah, Bank Sampah Enviro Andalas juga sudah memenuhi kriteria. Penabung sampah sudah dilengkapi dengan nomor rekening dan buku tabungan. Pelaksana bank sampah yang terdiri dari tim PPST (direktur dan manajer), petugas kontrak dan dibantu beberapa orang mahasiswa tim SWCT sudah dilengkapi dengan APD dalam pelayanan tabungan sampah serta pencacahan sampah plastik dan sudah melaksanakan monev setiap bulan untuk mengevaluasi kinerja bank sampah. Tim pelaksana ini pun sudah diberikan insentif setiap bulannya. 
Pengepul atau bandar daur ulang yang menjadi mitra Bank Sampah Enviro Andalas sudah memiliki izin usaha dan sudah mempunyai kesepakatan kerja sama/mou dengan bank sampah. Dalam pengelolaan bank sampah, penjualan sampah layak jual ke pengepul/bandar daur ulang telah dilakukan minimal satu kali sebulan, sedangkan sampah sisa (residu) yang tidak di daur ulang telah diangkut Dinas Kebersihan dan Pertamanan Kota Padang sekali seminggu. Cakupan pelayanan Bank Sampah Enviro Andalas mencakup seluruh masyarakat kampus Unand yang berjumlah sekitar 25.000 orang, sedangkan pelayanan minimal berdasarkan kriteria PermenLHRI no. 13 tahun 2012 pelayanan minimal 500 KK (2500-3000 orang). Hasil evaluasi terhadap jumlah nasabah, rata-rata ada penambahan nasabah 84 orang per bulan, dan telah memenuhi standar jumlah penambahan penabung perbulan sebesar 5 10 orang.

\section{Pelaksanaan Bank Sampah}

Pelaksanaan bank sampah berdasarkan pasal 6 Peraturan Menteri Negara Lingkungan Hidup Republik Indonesia no 13 tahun 2012 meliputi penetapan jam kerja, penarikan tabungan, peminjaman uang, buku tabungan, jasa penjemputan sampah, jenis tabungan, jenis sampah, penetapan harga, kondisi sampah, berat minimum dan wadah sampah.

Bank Sampah Enviro Andalas beroperasi setiap hari kerja dari jam 9.00 sd 15.00 . Dalam PermenLHRI no 13 tahun 2012, penetapan kerja bank sampah tidak diatur dan sepenuhnya tergantung dari kesepakatan pelaksana bank sampah dan masyarakat sebagai penabung. Sebagai contoh, jam kerja Bank Sampah Rejeki di Surabaya buka Jumat dan Sabtu pukul 15.00-17.00 serta Minggu pukul 09.00-17.00 (KLH, 2012).

Sesuai ketentuan yang berlaku di Bank Sampah Enviro Andalas, penarikan dana tabungan nasabah baru dapat dilakukan paling cepat sebulan setelah menabung. Dalam Lampiran II PermenLHRI no 13 tahun 2012 dianjurkan sampah yang ditabung tidak langsung diuangkan namun ditabung dan dicatat dalam buku rekening, dan baru dapat diambil paling cepat dalam 3 (tiga) bulan. Hal ini penting dalam upaya menghimpun dana yang cukup untuk dijadikan modal dan mencegah budaya konsumtif.

Selain menabung sampah, dalam prakteknya bank sampah juga dapat meminjamkan uang kepada penabung dengan sistem bagi hasil dan harus dikembalikan dalam jangka waktu tertentu (PermenLHRI no 13 tahun 2012). Namun dalam operasional Bank Sampah Enviro Andalas peminjaman uang oleh nasabah belum diberlakukan. Hal ini akan dibahas lebih lanjut sejalan dengan peningkatan umur operasional bank sampah.

Setiap sampah yang ditabung, ditimbang, dan dihargai sesuai harga pasaran sampah kemudian dicatat dalam buku rekening (buku tabungan) sebagai bukti tertulis jumlah sampah dan jumlah uang yang dimiliki setiap penabung. Dalam setiap buku rekening tercantum kolom kredit, debit, dan balans yang mencatat setiap transaksi yang pernah dilakukan (PermenLHRI no 13 tahun 2012). Hal ini sudah diterapkan dalam buku tabungan nasabah yang dikeluarkan Bank Sampah Enviro Andalas.

Dalam operasional Bank Sampah Enviro Andalas saat ini belum diberlakukan jasa penjemputan sampah oleh petugas bank sampah. Hal ini dikarenakan petugas bank sampah yang ada masih terbatas dan dalam operasional, bank sampah belum memiliki kendaraan operasional. Namun wacana ke depan, akan diberlakukan jasa penjemputan untuk sampah yang ditabung lebih dari 20 $\mathrm{kg}$. Hal ini juga sejalan dengan permintaan dari beberapa nasabah untuk diberlakukan jasa penjemputan sampah. Kendaraan operasional dapat digunakan kendaraan pengumpul sampah (motor sampah) yang dimiliki universitas, dengan memberlakukan pengaturan jadwal, sehingga tidak menggangu operasional pengumpulan sampah yang ada. Hal ini akan dibahas dengan pimpinan universitas

Sesuai PermenLHRI no 13 tahun 2012, dalam prakteknya, pengelola bank sampah dapat melaksanakan dua jenis tabungan, tabungan individu dan tabungan kolektif. Tabungan individu juga dapat terdiri dari beberapa jenis, tabungan biasa, tabungan pendidikan dan tabungan lebaran. Tabungan 
biasa penarikan dapat dilakukan setiap saat, tabungan pendidikan penarikan dapat dilakukan diawal tahun ajaran baru dan tabungan lebaran penarikan dilakukan seminggu sebelum lebaran. Tabungan kolektif biasanya ditujukan untuk keperluan kelompok. Di Bank Sampah Enviro Andalas sudah diberlakukan jenis tabungan individu dan kolektif, namun jenis tabungan baru tabungan biasa, yang penarikannya dapat dilakukan setiap saat. Namun ke depan direncanakan akan dikembangkan menjadi tabungan pendidikan, tabungan lebaran dan tabungan wisuda. Pada tabungan wisuda penarikan dapat dilakukan pada saat mahasiswa akan wisuda, sehingga akan meringankan biaya yang akan dikeluarkan dengan dana tabungan sampah mereka.

Jenis tabungan sampah yang diterima Bank Sampah Enviro Andalas saat ini adalah kelompok sampah plastik, sampah kertas dan logam (kaleng dan aluminium). Hal ini sudah sesuai dengan jenis tabungan sampah berdasarkan PermenLHRI no 13 tahun 2012 yang juga terbagi atas tiga kelompok sampah tersebut. Bank sampah masih dapat menerima sampah jenis lain dari penabung sepanjang mempunyai nilai ekonomi dan adanya permintaan pasar.

Penetapan harga setiap jenis sampah merupakan kesepakatan pengurus bank sampah. Harga setiap jenis sampah bersifat fluktuatif tergantung harga pasaran. Penetapan harga meliputi:

1. Untuk perorangan yang menjual langsung sampah dan mengharapkan uang tunai, harga yang ditetapkan merupakan harga fluktuatif sesuai harga pasar

2. Untuk penabung yang menjual secara kolektif dan sengaja untuk ditabung, harga yang diberikan merupakan harga stabil tidak tergantung pasar dan biasanya di atas harga pasar.

Cara ini ditempuh untuk memotivasi masyarakat agar memilah, mengumpulkan, dan menabung sampah. Cara ini juga merupakan strategi subsidi silang untuk biaya operasional bank sampah (PermenLHRI no 13 tahun 2012).

Penetapan harga sampah di Bank Sampah Enviro Andalas disesuaikan dengan harga pasar. Karena saat ini jenis tabungan yang ada masih merupakan tabungan biasa yang penarikannya dapat dilakukan setiap saat maka harga yang ditetapkan fuktuatif sesuai harga pasar. Ke depan dengan diberlakukan jenis tabungan lain yang diperuntukkan untuk menabung, penetapan harga adalah harga stabil yang tidak tergantung pasar dan biasanya di atas harga pasar.

Kondisi sampah yang ditabung diusahakan dalam keadaan bersih dan utuh, karena harga sampah dalam keadaan bersih dan utuh memiliki nilai ekonomi yang lebih tinggi. Untuk sampah plastik, penjualan dalam bentuk tercacah akan meningkatkan nilai ekonomi bisa tiga kali lipat dari bentuk sebelum tercacah. Dalam operasionalnya, Bank Sampah Enviro Andalas sudah menerapkan kriteria untuk kondisi sampah ini, yaitu menerima sampah dalam kondisi bersih dan utuh, serta telah mencacah sampah plastik.

Bank Sampah Enviro Andalas juga menerapkan berat minimum sampah yang ditabung yaitu minimal $1 \mathrm{~kg}$. Nasabah dianjurkan untuk menyimpan sampah yang belum mencapai berat minimum $1 \mathrm{~kg}$, sebelum nantinya ditabung ke bank sampah. Hal ini diberlakukan agar memudahkan dalam penimbangan dan pencatatan di buku tabungan. Selain itu nasabah juga dihimbau untuk memilah sampahnya ke dalam tiga wadah sesuai kelompok sampah yang ditabung yaitu sampah plastik, sampah kertas dan sampah logam.

Bank Sampah Enviro Andalas juga sudah menerapkan sistem bagi hasil, dengan besaran yang digunakan adalah 85:15 yaitu 85\% (delapan puluh lima persen) untuk penabung dan 15\% (lima belas persen) untuk pelaksana bank sampah. Hal ini sudah sesuai dengan sistem bagi hasil yang biasanya digunakan oleh bank sampah lainnya. Bank Sampah Enviro Andalas juga sudah memberikan upah yang layak kepada karyawan yang bekerja di bank sampah.

Selain evaluasi pelaksanaan bank sampah mengacu pada persyaratan dalam PermenLHRI no 13 tahun 2012, pembahasan juga dilakukan terhadap indikator berikut: 


\section{Jumlah Nasabah Bank Sampah}

Gambar 6 memperlihatkan jumlah nasabah Bank Sampah Enviro Andalas dari bulan Januari sd September tahun 2014. Dari grafik terlihat jumlah nasabah meningkat setiap bulannya, terutama pada bulan September peningkatan sangat tajam. Hal ini sejalan dengan intensifnya sosialisasi keberadaaan bank sampah dilakukan ke masyarakat kampus.

Jumlah nasabah Bank Sampah Enviro Andalas sampai bulan September 2014 berjumlah 757 orang. Kelompok nasabah bank sampah terbesar berasal dari kalangan mahasiswa dengan jumlah lebih dari $80 \%$, sisanya berasal dari dosen, karyawan dan umum (pedagang dan petugas cleaning service di lingkungan kampus)

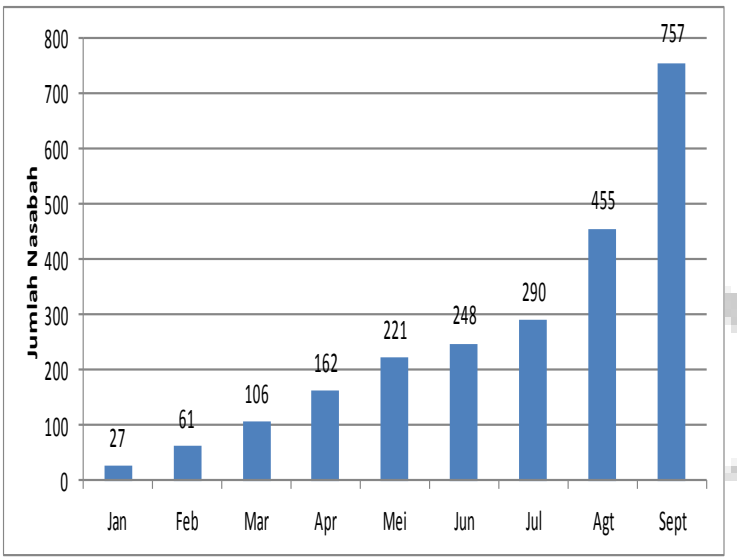

\section{Gambar 6 Jumlah Nasabah Bank} Sampah
Sosialisasi dilakukan melalui pembagian brosur, pemasangan poster dan banner serta pemberitaaan di milis dan web unand, yang sejalan dengan pemberitaan tentang PPST Unand. Sosialisasi juga dilakukan pada kegiatan atau even-even tertentu seperti sosialisasi di acara BAKTI mahasiswa baru, acara Dies Unand dan acara seminarseminar yang dilakukan di lingkungan kampus. Sosialisasi juga dilakukan terhadap warga pendatang yaitu pemilik kantin dan café serta petugas cleaning service. Bahkan dari warga pendatang ini diharapkan jumlah sampah yang ditabung menjadi lebih banyak. Kegiatan sosialisasi ini dapat dilihat pada Gambar 7.

\section{Jumlah Sampah yang Ditabung}

Saat ini sampah yang ditabung ke Bank Sampah Enviro Andalas dikelompokkan dalam sampah plastik, sampah kertas, sampah logam (kaleng dan sampah lainlain). Hal ini sesuai dengan permintaan pasar, bahan baku tersedia, kemampuan pengelola bank sampah serta kemampuan bandar daur ulang sebagai mitra yang akan membeli sampah ini nantinya. Jenis sampah yang dapat ditabung ini dapat dikembangkan sewaktu-waktu sesuai dengan permintaan pasar dan kemampuan mitra bank sampah. Gambar 8 memperlihatkan jumlah sampah yang ditabung di Bank Sampah Enviro Andalas.

\section{종 Universitas Andalas}

\section{Sosialisasi PPST Unand}

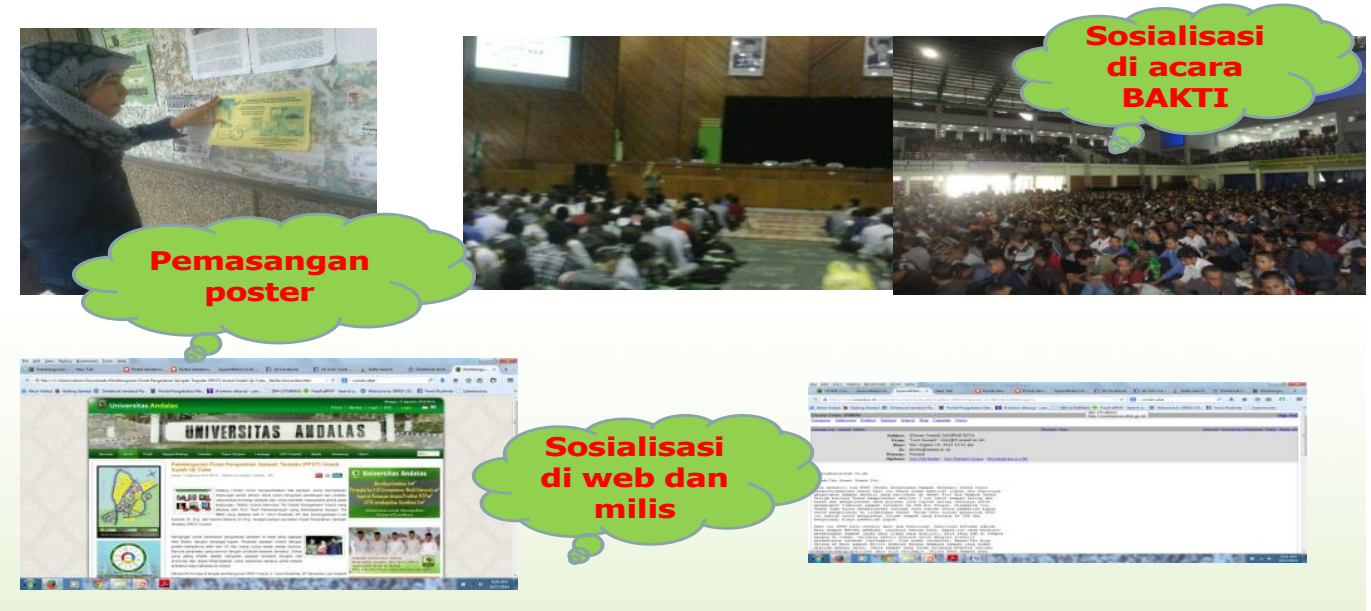

Gambar 7 Kegiatan Sosialisasi Bank Sampah Enviro Andalas 
Dari Gambar 8 terlihat jenis sampah terbanyak yang ditabung nasabah adalah sampah kertas dengan jumlah berfluktuasi antara 100 hingga $800 \mathrm{~kg} /$ bulan. Sampah kertas ini berupa kardus, kertas HVS, koran dan majalah bekas. Sampah plastik juga merupakan jenis sampah yang banyak ditabung dengan jumlah 20-60 kg/bulan. Jenis sampah plastik yang ditabung berupa bekas botol dan gelas plastik kemasan baik yang bening maupun berwarna serta karah. Berikutnya adalah sampah kaleng dengan jumlah rata-rata $10 \mathrm{~kg} /$ bulan.

Gambar 9 memperlihatkan jumlah sampah yang ditabung nasabah setelah dikonversi ke dalam rupiah. Jumlah tabungan sampah ini berkisar antara Rp. 250.000 sd Rp. 1.000.000 per bulan. Jumlah sampah yang ditabung terbesar adalah pada bulan September. Hal ini sejalan dengan intensifnya sosialisasi bank sampah dilakukan ke masyarakat kampus. Peningkatan jumlah sampah yang ditabung ini sesuai dengan peningkatan jumlah nasabah, yang juga terbesar pada bulan September. Pada bulan Juli dan Agustus, jumlah sampah yang ditabung ke bank sampah mengalami penurunan dibandingkan dengan bulan-bulan lainnya. Hal ini dikarenakan pada bulan Juli dan Agustus bertepatan dengan waktu liburan semester mahasiswa dan bulan puasa Ramadhan. Pada masa liburan, jumlah mahasiswa yang datang ke kampus juga lebih sedikit, begitu juga halnya dengan kantin/café banyak yang tutup karena bertepatan dengan bulanpuasa.

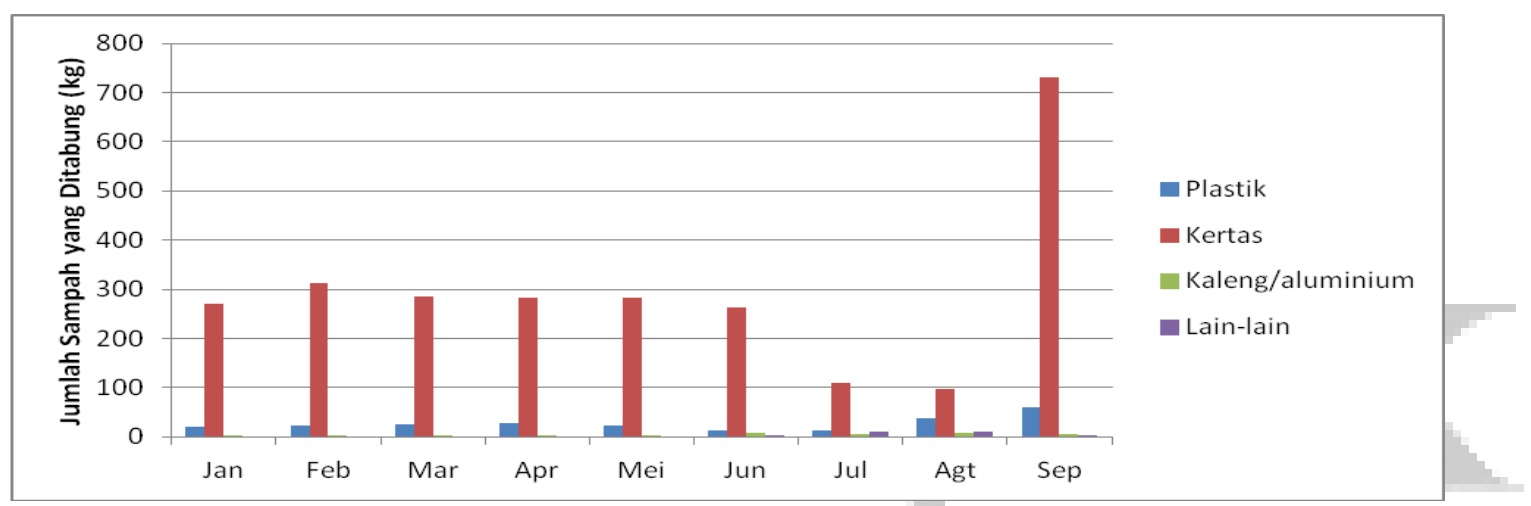

Gambar 8 Jumlah Sampah yang Ditabung (dalam kg)

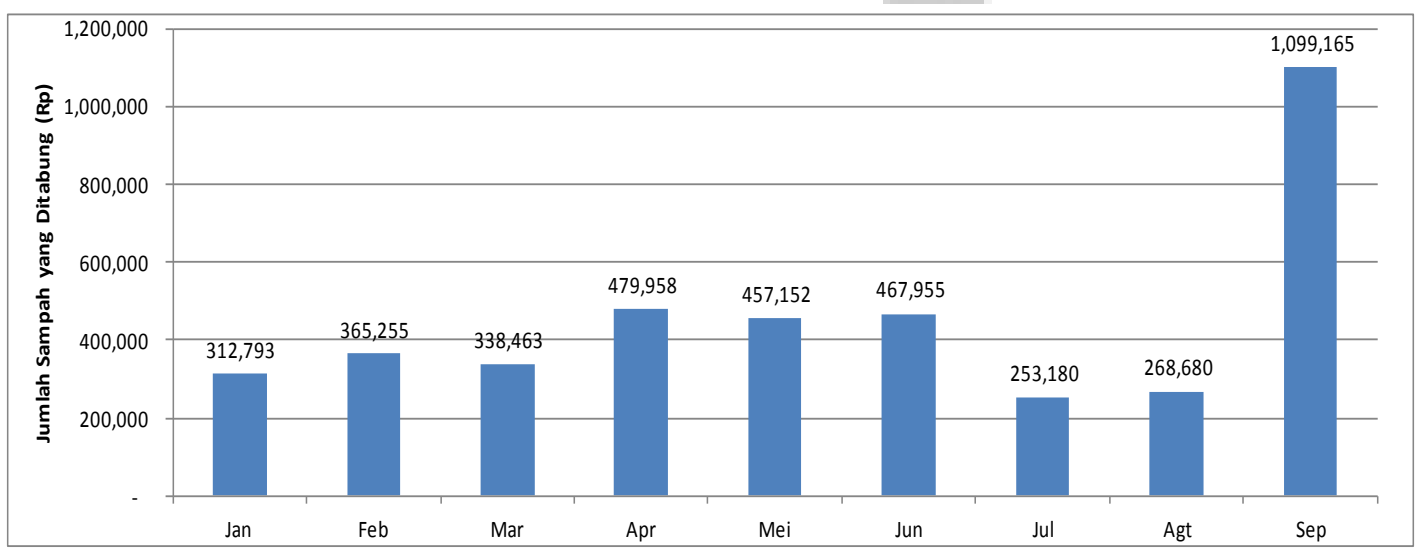

Gambar 9 Jumlah Sampah yang Ditabung (dalam Rupiah)

\section{Penjualan Sampah ke Bandar Daur Ulang}

Setelah sampah yang ditabung nasabah terkumpul dalam jumlah yang banyak, petugas sampah menghubungi mitra yaitu bandar daur ulang untuk menjual sampah tersebut. Penjualan sampah ke bandar daur ulang ini dilakukan 1 atau 2 kali dalam sebulan, tergantung jumlah sampah terkumpul. Gambar 10 memperlihatkan data penjualan sampah ke bandar daur ulang. Penjualan sampah berfluktuasi setiap 
bulannya dengan jumlah Rp 135.000 sd Rp. 950.000 .

Penjualan bulan Mei sd Agustus mengalami penurunan dikarenakan untuk jenis sampah plastik tidak dilakukan dulu penjualan, dikarenakan sampah plastik ini akan dicacah dan penjualan dilakukan dalam bentuk plastik tercacah. Pencacahan sampah plastik baru dilakukan pada bulan September, dikarenakan pengadaan dan install alat baru selesai dilakukan pada bulan Agustus. Hal ini mengakibatkan penjualan ke bandar daur ulang pada bulan September mengalami peningkatan dikarenakan adanya penjualan sampah plastik yang sudah dicacah

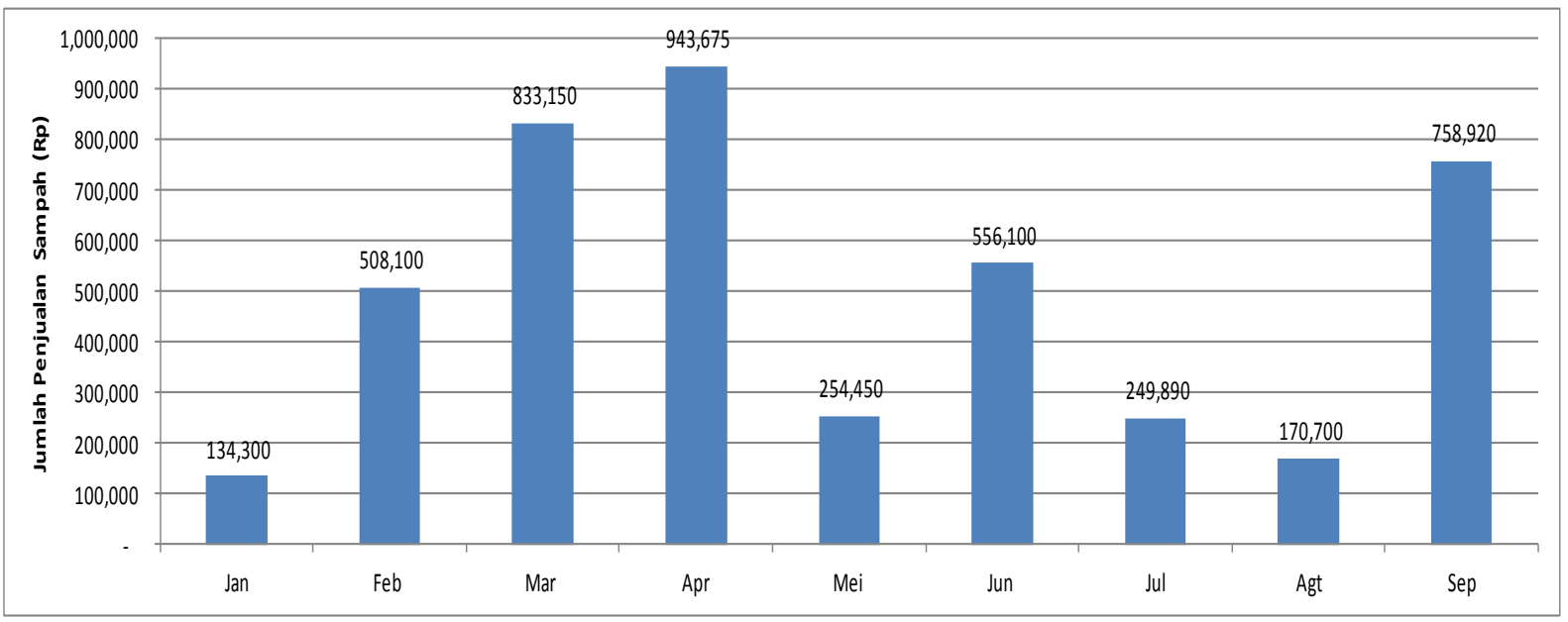

Gambar 10 Penjualan Sampah ke Bandar Daur Ulang

\section{Rekomendasi}

Hasil evaluasi pengelolaan sampah kering layak jual dengan penerapan bank sampah di kampus Unand hingga saat ini berjalan dengan baik. Bahkan tiap bulan mengalami peningkatan baik terhadap jumlah penabung sampah (nasabah), jumlah sampah yang ditabung dan penjualan sampah ke pengepul/bandar daur ulang. Namun peningkatan ini belum maksimal dikarenakan, sampah yang ditabung sebagian besar merupakan sampah yang dikumpulkan nasabah dari aktivitas perumahannya. Pengecualian untuk pedagang dan pemilik kantin di lingkungan kampus, sampah yang ditabung adalah dari aktivitas mereka berjualan di area kampus. Hal ini dikarenakan pemilahan di sumber belum optimal dilakukan pada masingmasing unit/bangunan.

Sebagai gambaran, jika dibandingkan jumlah sampah yang ditabung di bank sampah dengan jumlah sampah kering yang dapat didaur ulang dari perhitungan material balance, baru sekitar 10\% dari sampah dapat dikelola. Peningkatan ini masing dapat dimaksimalkan dengan melakukan upaya berikut:

- Mengintensifkan sosialisasi keberadaan bank sampah ke masyarakat kampus

- Memaksimalkan pemilahan sampah di sumber untuk masing-masing unit atau bangunan di lingkungan kampus

- Meningkatkan kerjasama dengan mitra sebagai pengepul/bandar daur ulang, sehingga dapat menambah jenis sampah yang akan ditabung

- Meningkatkan partisipasi aktif masyarakat kampus untuk memanfaatkan fasilitas bank sampah dalam pengelolaan sampah kering layak jual

- Memperkuat komitmen dari pimpinan untuk mendukung sepenuhnya pemilahan dan pengelolaan sampah di sumber sampah. Dukungan dapat dilakukan dengan surat edaran/himbauan ke masyarakat kampus untuk memilah sampah yang mereka hasilkan serta menabung sampah kering layak jual ke Bank Sampah Enviro Andalas.

Diharapkan nantinya Bank Sampah Enviro Andalas dapat berfungsi sebagai collection/dropping point, yaitu tempat 
dimana masyarakat dapat mengembalikan sampah dari

produk dan/atau kemasan yang layak daur ulang, guna ulang, dan/atau layak jual yang dikenai ketentuan EPR (Extended Producer Responsibility). EPR diartikan sebagai strategi yang didisain dalam upaya mengintegrasikan biaya-biaya lingkungan ke dalam seluruh proses produksi suatu barang sampai produk itu tidak dapat dipakai lagi (post consumer) sehingga biaya-biaya lingkungan menjadi bagian dari komponen harga pasar produk tersebut. Dengan strategi EPR tersebut, para produsen harus bertanggungjawab terhadap seluruh life cycle produk dan/atau kemasan dari produk yang mereka hasilkan. Ini artinya, perusahaan yang menjual dan/atau mengimpor

produk dan kemasan yang potensi menghasilkan sampah wajib bertanggungjawab, baik secara finansial maupun fisik, terhadap produk dan/atau kemasan yang masa pakainya telah usai (Damanhuri, 2004).

Mekanisme EPR yang umum digunakan adalah melalui penarikan kembali produk dan/atau kemasan yang habis masa pakainya (take-back systems). Melalui mekanisme ini, produsen (dalam hal ini termasuk di dalamnya pabrik, importer, distributor, dan retailer) yang dikenai ketentuan EPR wajib menarik kembali produk dan/atau kemasan yang sudah habis masa gunanya (post consumer) dari masyarakat. Sementara itu, masyarakat wajib memilah, mengumpulkan, dan menyerahkan produk dan/atau kemasan yang sudah habis masa gunanya ke tempattempat yang ditentukan (collection point atau droping point). Dalam hal ini bank sampah dapat berperan sebagai collection point atau droping point) (PermenLHRI no. 13 tahun 2012).

\section{SIMPULAN}

Pengelolaan sampah kering layak jual dengan penerapan bank sampah di kampus Unand telah memenuhi persyaratan yang berlaku sesuai dengan PermenLHRI no. 13 tahun 2012 baik persyaratan konstruksi dan persyaratan sistem manajemen bank sampah.
Operasional Bank Sampah Enviro Andalas juga sudah sesuai dengan ketentuan pelaksanaan bank sampah meliputi penetapan jam kerja, penarikan tabungan dan jenis tabungan, buku tabungan, jenis dan kondisi sampah, berat minimum dan wadah sampah. Untuk jasa penjemputan sampah dan peminjaman uang belum diberlakukan, namun akan diusahakan dalam pengembangan bank sampah selanjutnya.

Hasil evaluasi terhadap operasional bank sampah, terjadi peningkatan dalam jumlah nasabah, jumlah sampah yang ditabung dan penjualan sampah ke bandar daur ulang setiap bulannya. Namun peningkatan ini masih belum optimal jika dibandingkan dengan potensi daur ulang sampah kampus Unand

\section{Ucapan Terima Kasih}

Ucapan terima kasih disampaikan pada Ditjen Dikti yang telah membantu mendanai kegiatan pendirian PPST Unand melalui Hibah Pengabdian kepada Masyarakat dalam skim Inovasi bagi Inovasi Kreatifitas Kampus (IbIKK) Tahun 2014, Rektor Universitas Andalas dalam pembangunan fisik PPST Unand serta Lembaga Penelitian dan Pengabdian Masyarakat Universitas Andalas yang telah memfasilitasi kegiatan ini.

\section{DAFTAR PUSTAKA}

Chania, V, 2010. Timbulan, Komposisi dan Potensi Daur Ulang Sampah Kampus Universitas Andalas Limau Manis, Padang, Tugas akhir, Unand

Damanhuri, E. 2004. Diktat Pengelolaan Sampah. Bandung: Penerbit TL ITB.

Edwin, T, Ruslinda, Y, Abuzar SS, 2012. Pilot Project Sistem Pengelolaan Bank Sampah Fakultas Teknik Universitas Andalas. Laporan Akhir Kegiatan Pengabdian kepada Masyarakat DIPA FT Unand.

Kementerian Lingkungan Hidup, 2012. Profil Bank Sampah Indonesia 2012

Peraturan Menteri Negara Lingkungan Hidup Republik Indonesia no 13 tahun 2012. Pedoman Pelaksanaan Reduce, Reuse dan Recycle melalui Bank Sampah 
Amien, M, S., dkk. 2011. Materi Diseminasi Keteknikan Bidang Persampahan. http://www.sanitasi.or.id/ppsp/2012/01/ 27/materi-diseminasi-keteknikanbidang-persampahan/. Diunduh pada tanggal 17 Desember 2013.

Chania, V. 2010. Studi Timbulan, Komposisi, dan Potensi Daur Ulang Sampah Kampus Universitas Andalas Limau Manis. Tugas Akhir Jurusan Teknik Lingkungan. Unand. Padang.

Damanhuri, E. 2004. Diktat Pengelolaan Sampah. Bandung: Penerbit TL ITB.

Peraturan Menteri Pekerjaan Umum Nomor: 03/PRT/M/2013 tentang Penyelenggaraan Prasarana dan Sarana Persampahan dalam Penanganan Sampah Rumah Tangga dan Sampah Sejenis Sampah Rumah Tangga.

Peraturan Menteri Pekerjaan Umum Nomor: 21/PRT/M/2006 tentang Kebijakan dan Strategi Nasional Pengembangan Sistem Pengelolaan Persampahan (KSNP-SPP).

Peraturan Menteri Pendidikan dan Kebudayaan Republik Indonesia Nomor 25 Tahun 2012 tentang Organisasi dan Tata Kerja Universitas Andalas.
Putri, A. A. 2010. Pengembangan Sistem Pengolahan Persampahan Kampus Unand Limau Manis. Tugas Akhir Jurusan Teknik Lingkungan. Unand. Padang.

Santosa, B., Sofyan, H., dan Widiyastuti, W. A., 2008. Sistem Informasi Geografis Penyebaran Penduduk Berdasarkan Tingkat Usia di Kabupaten Sleman Berbasis Web. Volume 1979-2328.

Slamet, R., Yenni, R., dan Rizki, A., 2013. Studi Pemanfaatan Sampah Di Universitas Andalas. Vol.10 (1) : 77-82.

SNI 19-2454-2002 tentang Tata Cara Teknik Operasional Sampah Perkotaan.

SNI 3242-2008 tentang Pengelolaan Sampah di Permukiman.

Undang-Undang Nomor 18 Tahun 2008 tentang Pengelolaan Sampah.

Ruslinda, Y., Raharjo, S., Susanti, L.,2014, Kajian Penerapan Konsep Pengolahan Sampah Terpadu di Lingkungan Kampus Universitas Andalas. Prosiding Seminar Nasional Sains dan Teknologi Lingkungan I, Padang

Utami, E., 2013. Buku Panduan Sistem Bank Sampah dan 10 Kisah Sukses, Yayasan Unilever Indonesia, Jakarta

UU RI no. 18 Tahun 2008. Pengelolaan Sampah 